\title{
Klasifikasi Tingkat Keparahan Non-Proliferativel Diabetic Retinopathy Bedasarkan Hard Exudate Menggunakan Extreme Learning Machine
}

\author{
Dinda Ulima Rizky Yani dan Dwi Ratna Sulistyaningrum \\ Departemen Matematika, Fakultas Matematka dan Ilmu Pengetahuan Alam, Institut Teknologi \\ Sepuluh Nopember (ITS) \\ e-mail:dwiratna.math@gmail.com
}

\begin{abstract}
Abstrak-Diabetic Retinopathy dapat menyebabkan seseorang kehilangan kemampuan penglihatannya dan pada keadaan yang parah dapat mengakibatkan kebutaan. Tingkat keparahan NonProliferative Diabetic Retinopathy (NPDR) dapat diketahui dengan mendeteksi kelainan berupa hard exudate pada retina, namun diagnosanya tidak bisa dilakukan dengan cepat karena pengamatan retina harus melewati beberapa proses. Teknologi pengolahan citra digital berbasis machine learning telah banyak digunakan untuk menyelesaikan permasalahan ini. Pada Tugas Akhir ini telah dilakukan penelitian untuk mengklasifikasikan tingkat keparahan NPDR secara otomatis dengan mengekstraksi karakteristik hard exudate menggunakan Gray Level Cooccurrence Matrix (GLCM) dan Neighborhood Gray-tone Difference Matrix (NGTDM) kemudian menentukan tingkat keparahannya menggunakan Extreme Learning Machine. Hasil akurasi tertingi yang didapat sebesar $91,22 \%$ untuk ekstraksi ciri dengan menggunakan GLCM.
\end{abstract}

Kata Kunci-Diabetic Retinopathy, Extreme Learning Machine, hard exudate, NPDR, Pengolahan Citra.

\section{PENDAHULUAN}

$\mathrm{D}$ IABETES telah menyebabkan lebih dari tiga juta kematian di dunia setiap tahunnya. World Health Organization (WHO) melaporkan pada tahun 2014 sebanyak 422 juta orang menderita penyakit ini [1]. Jumlah ini diprediksi akan meningkat sebanyak dua kali lipat untuk 20 tahun mendatang [2]. Diabetes yang tidak terkontrol dalam jangka waktu lama dapat menyebabkan komplikasi penyakit seperti serangan jantung, stroke, gagal ginjal bahkan kebutaan. Diabetes yang paling banyak diderita adalah diabetes melitus. Semakin lama seseorang menyandang diabetes melitus maka semakin besar pula kemungkinan ia akan terkena Diabetic Retinopathy. Diabetic Retinopathy merupakan komplikasi diabetes melitus yang ditandai dengan munculnya kelainan (luka) pada retina. Keterlambatan diagnosa Diabetic Retinopathy dapat menyebabkan penderita kehilangan kemampuan penglihatannya sampai akhirnya mengalami kebutaan. Tentu saja hal ini dapat menurunkan kualitas hidup penderita.

Penentuan tingkat keparahan Diabetic Retinopathy dilakukan dengan mendeteksi kelainan pada retina. Namun untuk mendeteksi kelainan pada retina tidak bisa dilakukan dengan mata telanjang melainkan harus menggunakan citra fundus retina atau pengamatan retina menggunakan kamera fundus. Pada Non-Proliferative Diabetic Retinopathy (NPDR) dapat terjadi gejala Retinopathy yang berbeda seperti microaneuriysms, haemorrhages, dan hard exudate yang merupakan luka pada retina. Penderita Diabetic Retinopathy tingkat sedang dan parah beresiko mengalami kebutaan karena macula pada retina akan tertutup oleh hard exudate sehingga harus mendapatkan penangan yang cepat. Namun pengamatan citra fundus retina ini harus melewati beberapa proses seperti menilai warna jingga pada retina, mengamati tepian dan warna optic disk kemudian menilai retina secara keseluruhan sehingga diagnosa tingkat keparahan NPDR tidak bisa dilakukan dengan cepat. Untuk menyelesaikan permasalahan tersebut dibutuhkan teknologi untuk memproses citra fundus retina secara cepat dan akurat untuk membantu dokter menetapkan tindakan medis yang tepat. Teknologi yang mampu mengklasifikasikan tingkat keparahan Diabetic Retinopathy adalah pengolahan citra digital berbasis machine learning.

Pengolahan citra digital dipilih sebagai teknologi yang tepat karena mampu menganalisis suatu citra dan mengekstraksi fitur-fiturnya dengan tepat dan jelas sehingga citra mudah untuk diteliti. Teknologi pengolahan citra digital berbasis machine learning sudah banyak digunakan dalam bidang medis. Pada Tugas Akhir ini telah diajukan algoritma Extreme Learning Machine sebagai metode untuk mengklasifikasi tingkat keparahan Non-Proliferative Diabetic Retinopathy. Alasan digunakannya metode Extreme Learning Machine adalah karena metode ini telah mampu mengklasifikasi retina mata yang normal dan abnormal secara cepat dan akurat [3].

Ada pun beberapa penelitian mengenai Diabetic Retinopathy yang telah dilakukan adalah "Classification of Non-Proliferative Diabetic Retinopathy Based on Hard Exudate Using Soft Margin SVM" oleh Handayani Tjandrasa, dkk pada tahun 2013. Hal yang paling disoroti dalam penelitian tersebut adalah segmentasi exudate pada citra fundus retina. Hasil segmentasi exudate ini berupa citra biner yang kemudian di ekstraksi menggunakan parameter area, perimeter, jumlah centroid dan standar deviasi. Hasil klasifikasi pada penelitian ini menunjukkan tingkat akurasi yang baik yaitu sebesar 90,54\% [4]. 
Selain itu pada tahun 2014, Gowthaman melakukan penelitian yang berjudul "Automatic Identification and Classification of Microaneurysms for Detection of Diabetic Retinopathy". Pada penelitian tersebut Gowthaman membandingkan kinerja metode SVM dan ELM untuk mengidentifikasi dan mengklasifikasi microaneuriysms untuk mendeteksi DR. Pada tahap preprocessing, noise pada citra fundus retina dihilangkan kemudian dilakukan penajaman kontras. Setelah itu dilakukan segmentasi microaneuriysms untuk memisahkan pembuluh darah dari retina lalu diekstraksi. Setelah didapatkan ekstraksi fiturnya kemudian citra diklasifikasian kedalam 2 kelas yaitu normal (tidak terdapat microaneuriysms) dan abnormal (terdapat microaneuriysms). Dari hasil penelitian tersebut metode ELM kinerja yang sangat baik dalam hal efisiensi dan waktu komputasi karena membutuhkan waktu eksekusi lebih sedikit dibadingkan dengan SVM [5].

\section{PERANCANGAN SISTEM}

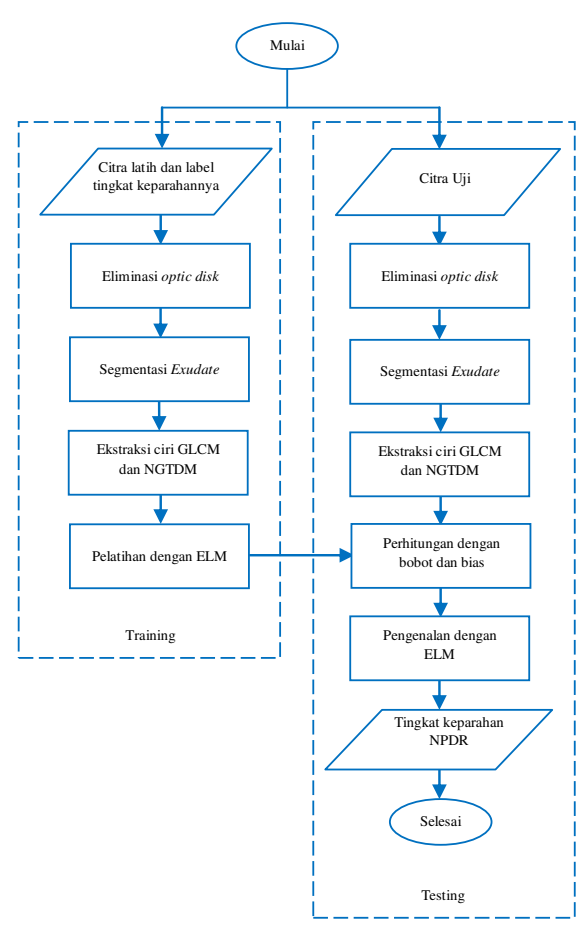

Gambar 1. Diagram klasifikasi tingkat keparahan NPDR.

\section{A. Praproses Data}

Citra fundus retina yang digunakan pada penelitian ini merupakan citra yang tidak melalui proses kompresi sehingga harus melalui proses resize normalisasi menjadi ukuran $384 \times 576$ piksel agar citra dapat diolah dengan mudah oleh sistem. Ada dua tahap penting pada proses ini yaitu eliminasi optic disk dan segmentasi exudate.

\section{Eliminasi Optic Disk}

Optic disc merupakan salah satu bagian utama pada retina. Sebelum dilakukan proses segmentasi exudate, lingkaran optic disk harus dieliminasi dari citra dengan tujuan untuk menghilangkan daerah palsu yang memiliki kesamaan ciri dengan exudate. Citra retina yang telah melalui proses resize diekstraksi ke dalam Red Channel dan Green Channel. Setelah itu dilakukan peregangan kontras agar area-area gelap pada citra menjadi lebih terang. Citra hasil peregangan kontras di filter menggunakan median filter untuk menghilangkan noisenya. Selanjutnya dicari centroid dari lingkaran optic disk untuk menentukan posisi optic disk pada citra. Proses ini ditunjukkan pada Gambar 2.

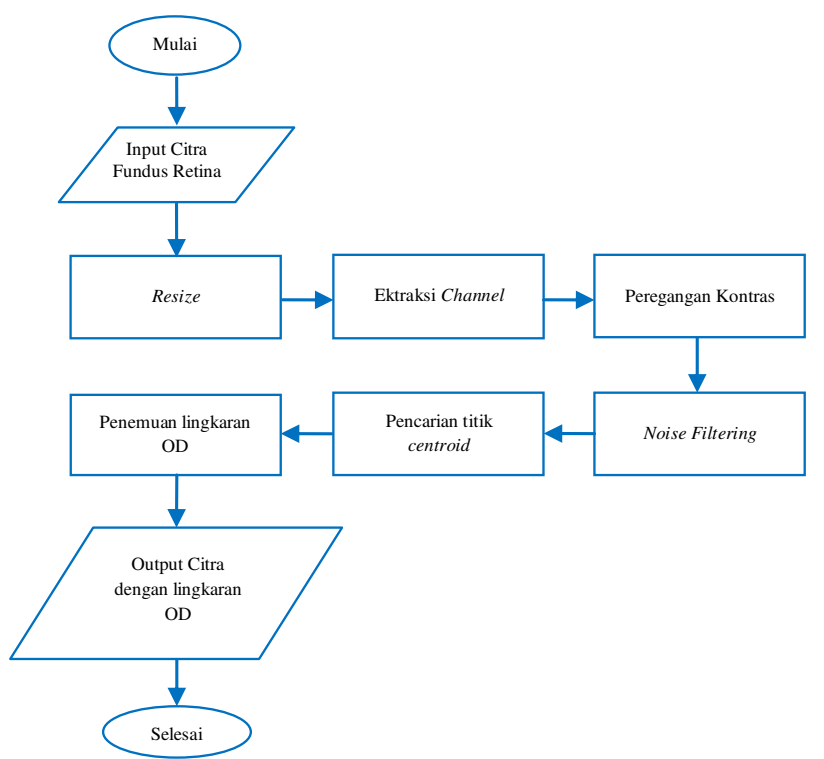

Gambar 2. Diagram alir proses eliminasi optic disk.

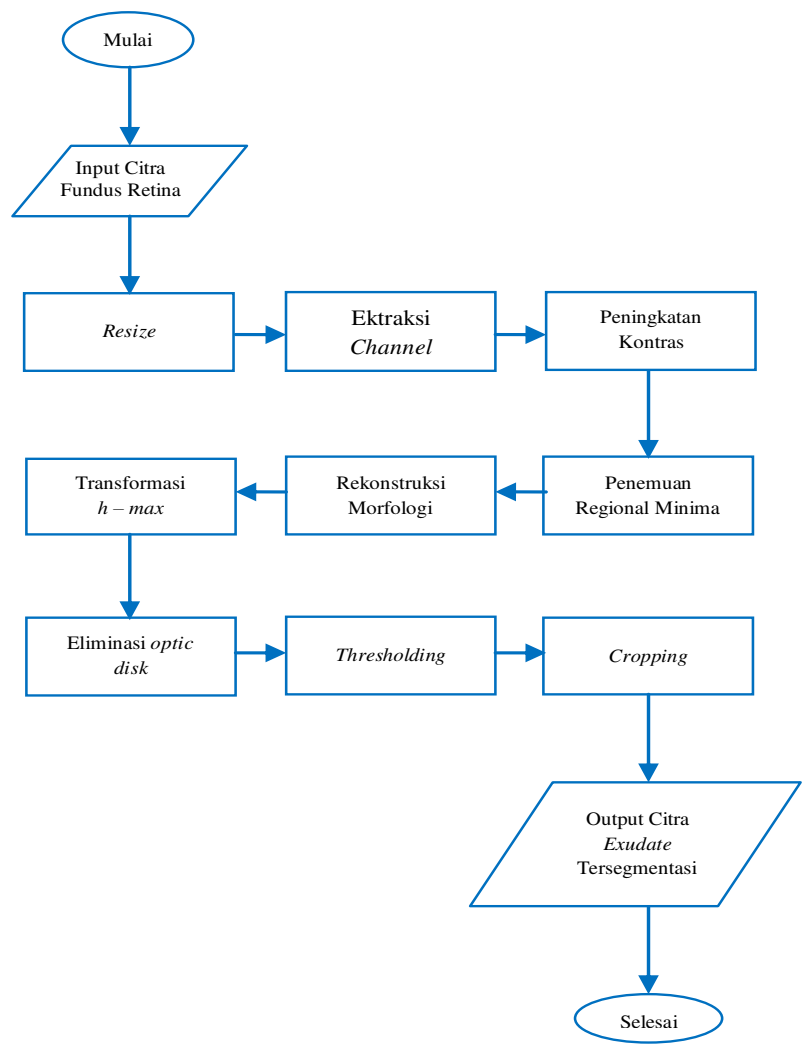

Gambar 3. Diagram alir proses eliminasi optic disk.

\section{Segmentasi Exudate}

Proses segmentasi dilakukan untuk mempertegas daerah hard exudate pada citra fundus retina sehingga dapat 
dideskripsikan dan dikenali. Citra fundus retina yang telah melalui proses eliminasi optic disk disegmentasi menggunakan metode thresholding Otsu untuk memisahakan daerah exudate dan non-exudate. Citra retina yang telah melalui proses resize diubah ke dalam citra gray dan diekstraksi channelnya. Kemudian dilakukan operasi morfologi peningkatan kontras dan menemukan regional minima dari citra hasil peningkatan kontras untuk menandai area-area citra yang memiliki nilai intensitas yang rendah. Setelah itu dilakukan transformasi $h$ maxima untuk menghilangkan area yang memiliki nilai intensitas yang rendah. Citra hasil transformasi h-maxima disubstraksi dengan wilayah optic disk yang telah ditemukan pada proses eliminasi optic disk. Setelah optic disk hilang dari citra, dilakukan proses thresholding untuk menentukan wilayah exudate dan non-exudate. Terakhir dilakukan cropping citra hasil thresholding untuk mengembalikan nilai asli dari exudate yang telah ditandai. Proses ini ditunjukkan pada Gambar 3.

\section{B. Ekstraksi Ciri}

Informasi yang diekstrak dari citra exudate yang telah tersegmentasi merupakan ciri statistik orde kedua. Fitur-fitur ini didapatkan dengan menggunakan GLCM (Gray Level Cooccurrence Matrix) dan NGTDM (Neighorhood Gray-tone Difference Matrix). GLCM mengekstraksi ciri citra menggunakan gray level matrix atau matrik derajat keabuan dengan berbagai orientasi sudut $(\theta)$ dan jarak spasial $(d)$. Elemen-elemen yang dapat diekstrak menggunakan GLCM antara lain: angular second moment (energy), contrast, correlation, dissimilarity, inverse difference moment (homogeneity), dan entropy [6]. Sedangkan NGTDM menggambarkan fitur lokal dengan menghitung parameter tekstur tingkat tinggi menggunakan gray-tone (tingkat kegelapan atau tingkat kecerahan) obyek pada citra. Karakteristik tekstur citra yang diturunkan dari NGTDM sesuai dengan karakteristik citra menurut presepsi manusia, yaitu: coarsness, contrast, bussyness, complexity, dan texture strength [7].

\section{Pemodelan Extreme Learning Machine}

Extreme Learning Machine terdiri dari 3 layer yaitu input layer, hidden layer, dan output layer [8]. Input layer dan hidden layer dihubungkan oleh vektor bobot $w$ yang nilainya ditentukan secara acak. Bias yang terhubung dengan nodenode pada hidden layer juga ditentukan secara acak. Input untuk jaringan berupa karakteristik dari 105 citra yang berbeda yang masing-masing berisi ciri statistik karakteristik exudate yang merupakan hasil dari ekstraksi ciri. Jumlah node pada layer pertama sama dengan jumlah ciri statistik yang menjadi input. Dalam penelitian ini hasil paling optimal diperoleh dengan menggunakan 6 node pada input layer yang setiap nodenya merepresentasikan satu ciri yang diekstraksi dari citra.

Untuk setiap pasangan input dan target output $\left(x_{i}, t_{i}\right)$, dihitung nilai matriks dengan persamaan berikut:

$$
H_{i, j}=g\left(w_{i} \cdot x_{j}+b_{i}\right)
$$

Keterangan:

$$
\mathrm{H} \quad=\text { matriks output pada hidden layer }
$$

$$
\begin{aligned}
& w=\text { vektor bobot yang menghubungkan hidden node } \\
& \text { dan input node } \\
& x=\text { matriks input } \\
& b \quad=\text { bias yang terhubung dengan hidden node } \\
& w \cdot x=\text { inner product dari } w \text { dan } x \\
& g \quad \text { = fungsi aktivasi } \\
& i \quad=\text { indeks jumlah node pada hidden layer } \\
& j \quad=\text { indeks jumlah citra input }
\end{aligned}
$$

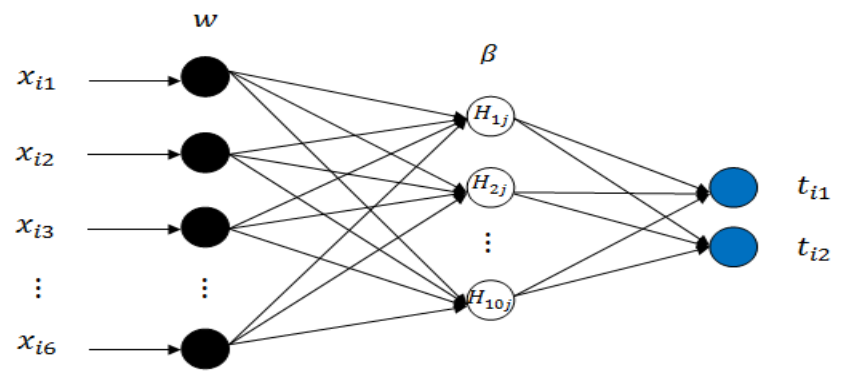

Input Layer Hidden Layer Output Layer

Gambar 4. Desain arsitektur Extreme Learning Machine yang digunakan.

Matriks $\mathrm{H}$ digunakan untuk menghitung vektor bobot $\beta$ menggunakan persamaan berikut:

$$
\mathrm{H} \beta=\mathrm{T}
$$

dengan,

$$
\begin{gathered}
H=\left[\begin{array}{ccc}
g\left(w_{1} \cdot x_{1}+b_{1}\right) & \cdots & g\left(w_{10} \cdot x_{1}+b_{10}\right) \\
\vdots & \ddots & \vdots \\
g\left(w_{1} \cdot x_{105}+b_{1}\right) & \cdots & g\left(w_{10} \cdot x_{105}+b_{10}\right)
\end{array}\right] \\
\beta=\left[\begin{array}{c}
\beta_{1}^{T} \\
\vdots \\
\beta_{10}^{T}
\end{array}\right] \text { dan } T=\left[\begin{array}{c}
T_{1}^{T} \\
\vdots \\
T_{105}^{T}
\end{array}\right]
\end{gathered}
$$

Keterangan:

$\mathrm{H} \quad$ : matriks output pada hidden layer

$\beta$ : vektor bobot yang menghubungkan hidden node dan output node

$T \quad$ : matriks target

Berdasarkan Persamaan (2.2) bobot output $\beta$ yang berhubungan dengan hidden layer dapat dihitung menggunakan persamaan berikut:

$$
\beta=\mathrm{H}^{\dagger} \mathrm{T}
$$

dengan $\mathrm{H}^{\dagger}$ merupakan Moore-Penrose generalized inverse dari $\mathrm{H}$.

1) Proses Training

Proses ini menghasilkan keluaran berupa bobot $\beta$ yang digunakan untuk menentukan kelas pada proses testing. Pada proses training, setelah seluruh citra input disegmentasi dan diekstraksi ciri, nilai seluruh ciri statistik ini dimasukkan ke dalam sistem klasifikasi, kemudian sistem menentukan nilai bobot $w$ dan bias $b$. Setelah bobot dan bias terbentuk selanjutnya dihitung nilai matriks $\mathrm{H}$. Invers dari Matriks $H$ ini digunakan untuk menghitung nilai bobot $\beta$ menggunakan Persamaan (2.3). 


\section{2) Proses Testing}

Data masukan pada proses ini adalah ciri statistik dari citra fundus retina yang telah melalui tahap eliminasi optic disk dan segmentasi exudate. Bobot $w$ dan bias $b$ yang digunakan pada proses ini sama dengan bobot dan bias yang digunakan pada saat training. Selanjutnya, dihitung nilai matriks $\mathrm{H}$ menggunakan persamaan (2.1). Setelah matriks $\mathrm{H}$ didapat selanjutnya dihitung nilai output menggunakan persamaan berikut:

$$
o=\sum_{i=1}^{10} \beta_{i} g\left(w_{i} \cdot x+b_{i}\right)
$$

\section{IMPLEMENTASI SISTEM}

\section{A. Dataset Training dan Testing}

Data yang digunakan pada penelitian ini berupa citra fundus retina yang diambil dari dataset MESSIDOR [9]. Citra fundus retina yang digunakan adalah citra retina yang mengandung hard exudate dan teridentifikasi moderate NPDR atau severe NPDR seerti ditunjukkan pada Gambar 5.

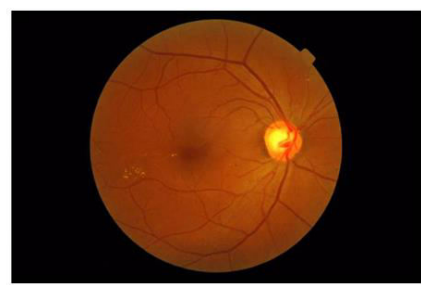

(a)

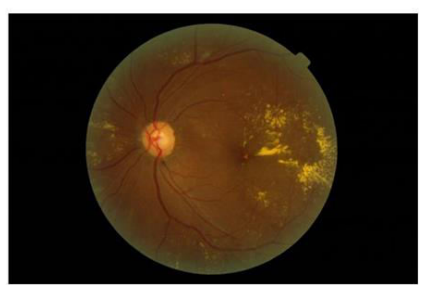

(b)
Gambar 5. Citra input (a) moderate NPDR, (b) severe NPDR.

\section{B. Hasil Pengujian}

Pengujian yang dilakukan meliputi pengujian tahap praproses data dan pengujian tahap klasifikasi dengan metode Extreme Learning Machine. Pengujian sistem dilakukan terhadap data training dan data testing. Data training sebanyak 105 citra retina yang terdiri dari 45 citra teridentifikasi moderate NPDR dan 60 citra teridentifikasi severe NPDR. Data testing sebanyak 34 citra retina yang terdiri dari 17 citra teridentifikasi moderate NPDR dan 17 citra teridentifikasi severe NPDR.

\section{Pengujian Tahap Praproses Data}

Pengujian ini dilakukan terhadap proses-proses pada tahap pengolahan citra. Pengujian bertujuan untuk mengetahui bahwa proses-proses pada tahap pengolahan citra sudah benar. Pada tahap ini terdapat 2 proses yaitu eliminasi optic disk dan segmentasi exudate. Pengujian proses eliminasi optic disk bertujuan untuk menghilangkan wilayah optic disk sebelum exudate di segmantasi. Hasil pengujian proses ini ditunjukkan pada Gambar 6.

Pengujian proses segmentasi exudate bertujuan untuk menemukan wilayah exudate pada citra fundus retina. Hasil pengujian proses ini ditunjukkan pada Gambar 7. Citra exudate tersegmentassi ini diekstraksi karakteristiknya menggunakan GLCM dan NGTDM. Hasil ekstraksi ciri ini digunakan sebagai input pada proses klasifikasi.

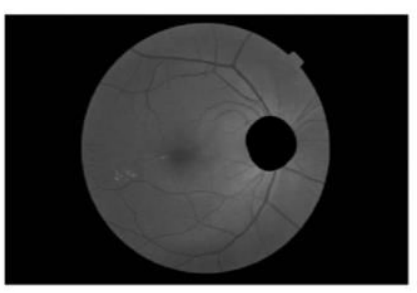

(a)

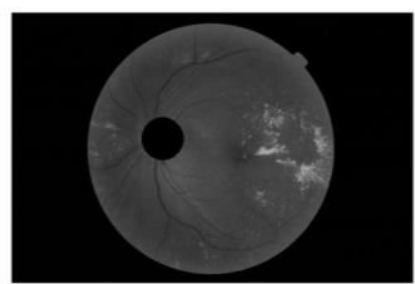

(b)
Gambar 6.. Pengujian proses eliminasi optic disk pada citra: (a) moderate NPDR, (b) severe NPDR.

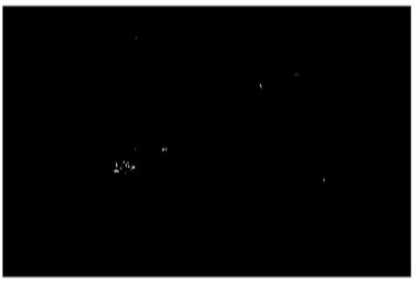

(a)

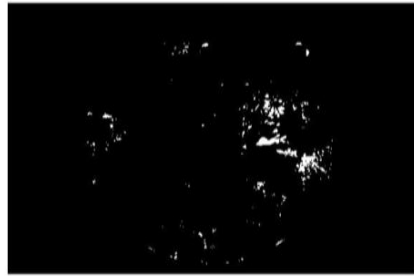

(b)
Gambar 7. Pengujian proses segmentasi exudate pada citra: (a) moderate NPDR, (b) severe NPDR.

\section{Pengujian Tahap Klasifikasi Menggunakan Extreme} Learning Machine

Pengujian proses ini dilakukan untuk menentukan apakah suatu citra fundus retina merupakan retina yang teridentifikasi moderate NPDR atau severe NPDR. Pada penelitian ini pengujian dilakukan pada 3 kasus yaitu ekstraksi ciri menggunakan GLCM saja, ekstraksi ciri menggunakan NGTDM saja, dan ekstraksi ciri menggunakan GLCM dan NGTDM. Masing masing kasus diuji menggunakan fungsi aktivasi yang berbeda yaitu fungsi sigmoid biner, fungsi sigmoid bipolar, dan fungsi softsign. Penggunaan fungsi aktivasi dan parameter ciri statistik yang digunakan berbedabeda, artinya untuk setiap kasus model Extreme Learning Machine yang digunakan akan berbeda.

Pengujian pertama dilakukan dengan ekstraksi ciri menggunakan GLCM. Dengan menggunakan fungsi aktivasi sigmoid biner, untuk data testing didapatkan jumlah citra retina yang diklasifikasikan ke tingkat keparahan yang tepat sebanyak 29 dari total 34 citra. Untuk data training didapatkan jumlah citra retina yang diklasifikasikan ke tingkat keparahan yang tepat sebanyak 100 dari total 105 citra.

Dengan menggunakan fungsi aktivasi sigmoid bipolar, untuk data testing didapatkan jumlah citra retina yang diklasifikasikan ke tingkat keparahan yang tepat sebanyak 29 dari total 34 citra dan untuk data training didapatkan jumlah citra retina yang diklasifikasikan ke tingkat keparahan yang tepat sebanyak 102 dari total 105 citra. Sedangkan dengan menggunakan fungsi aktivasi softsign, untuk data testing didapatkan jumlah citra retina yang diklasifikasikan ke tingkat keparahan yang tepat sebanyak 29 dari total 34 citra dan untuk data training didapatkan jumlah citra retina yang diklasifikasikan ke tingkat keparahan yang tepat sebanyak 101 dari total 105 citra. Rincian hasil pengujian ini disajikan pada Tabel 1 dengan $\mathrm{M}$ adalah moderate dan $\mathrm{S}$ adalah severe. Hasil perhitungan akurasi disajikan dalam Tabel 2. 
Tabel 1.

Hasil pengujian dengan ekstraksi ciri GLCM

\begin{tabular}{|c|c|c|c|c|c|}
\hline \multirow{2}{*}{$\begin{array}{c}\text { Fungsi } \\
\text { Aktivasi }\end{array}$} & \multirow{2}{*}{$\begin{array}{l}\text { Hasil } \\
\text { Output }\end{array}$} & \multicolumn{2}{|c|}{$\begin{array}{c}\text { Data } \\
\text { Testing }\end{array}$} & \multicolumn{2}{|c|}{ Data Training } \\
\hline & & $\mathrm{M}$ & $S$ & $\mathrm{M}$ & $\mathrm{S}$ \\
\hline \multirow{2}{*}{$\begin{array}{c}\text { Sigmoid } \\
\text { Biner }\end{array}$} & $\mathrm{M}$ & 13 & 1 & 43 & 3 \\
\hline & S & 4 & 16 & 2 & 57 \\
\hline \multirow{2}{*}{$\begin{array}{l}\text { Sigmoid } \\
\text { Bipolar }\end{array}$} & M & 14 & 2 & 44 & 2 \\
\hline & S & 3 & 15 & 1 & 58 \\
\hline \multirow{2}{*}{ Soft Sign } & M & 16 & 4 & 43 & 2 \\
\hline & S & 1 & 13 & 2 & 58 \\
\hline
\end{tabular}

Tabel 2.

Hasil perhitungan akurasi dengan ekstraksi ciri GLCM

\begin{tabular}{cccc}
\hline \hline Fungsi & Data & Akurasi & Akurasi Total \\
Aktivasi & Training & $95,24 \%$ & \multirow{2}{*}{$90,26 \%$} \\
Sigmoid & Testing & $85,29 \%$ & \\
Biner & Training & $97,14 \%$ & \multirow{2}{*}{$91,22 \%$} \\
Sigmoid & Testing & $85,29 \%$ & \\
Bipolar & Training & $96,19 \%$ & \multirow{2}{*}{ (29,74\% } \\
Soft Sign & Testing & $85,29 \%$ & \\
&
\end{tabular}

Pengujian kedua dilakukan dengan ekstraksi ciri menggunakan NGTDM. Dengan menggunakan fungsi aktivasi sigmoid biner, untuk data testing didapatkan jumlah citra retina yang diklasifikasikan ke tingkat keparahan yang tepat sebanyak 28 dari total 34 citra dan untuk data training didapatkan jumlah citra retina yang diklasifikasikan ke tingkat keparahan yang tepat sebanyak 100 dari total 105 citra.

Dengan menggunakan fungsi aktivasi sigmoid bipolar, untuk data testing didapatkan jumlah citra retina yang diklasifikasikan ke tingkat keparahan yang tepat sebanyak 28 dari total 34 citra dan untuk data training didapatkan jumlah citra retina yang diklasifikasikan ke tingkat keparahan yang tepat sebanyak 93 dari total 105 citra. Sedangkan dengan menggunakan fungsi aktivasi softsign, untuk data testing didapatkan jumlah citra retina yang diklasifikasikan ke tingkat keparahan yang tepat sebanyak 29 dari total 34 citra dan untuk data training didapatkan jumlah citra retina yang diklasifikasikan ke tingkat keparahan yang tepat sebanyak 101 dari total 105 citra. Rincian hasil pengujian ini disajikan pada Tabel 3 dan hasil perhitungan akurasinya disajikan dalam Tabel 4.

Tabel 3.

Hasil pengujian dengan ekstraksi ciri NGTDM

\begin{tabular}{|c|c|c|c|c|c|c|}
\hline \multirow[b]{2}{*}{$\begin{array}{c}\text { Fungsi } \\
\text { Aktivasi }\end{array}$} & \multirow[b]{2}{*}{$\begin{array}{l}\text { Hasil } \\
\text { Output }\end{array}$} & \multirow{2}{*}{$\begin{array}{l}\text { Citra } \\
\text { Input }\end{array}$} & \multicolumn{2}{|c|}{ DataTesting } & \multicolumn{2}{|c|}{ Data Training } \\
\hline & & & $\mathrm{M}$ & $\mathrm{S}$ & M & $\mathrm{S}$ \\
\hline \multirow{2}{*}{$\begin{array}{c}\text { Sigmoid } \\
\text { Biner }\end{array}$} & $\mathrm{N}$ & & 12 & 1 & 42 & 2 \\
\hline & $s$ & & 5 & 16 & 3 & 58 \\
\hline \multirow{2}{*}{$\begin{array}{l}\text { Sigmoid } \\
\text { Bipolar }\end{array}$} & $\mathrm{N}$ & & 14 & 3 & 43 & 10 \\
\hline & $S$ & & 3 & 14 & 2 & 50 \\
\hline \multirow{2}{*}{ Softsign } & $\mathrm{N}$ & & 13 & 1 & 42 & 1 \\
\hline & $s$ & & 4 & 16 & 3 & 59 \\
\hline
\end{tabular}

Tabel 4

Hasil perhitungan akurasi dengan ekstraksi ciri NGTDM

\begin{tabular}{cccc}
\hline \hline Fungsi Aktivasi & Data & Akurasi & Akurasi Total \\
\hline Sigmoid & Training & $95,24 \%$ & \multirow{2}{*}{$88,79 \%$} \\
Biner & Testing & $82,35 \%$ & \\
Sigmoid & Training & $88,57 \%$ & $85,46 \%$ \\
Bipolar & Testing & $82,35 \%$ & \\
& Training & $96,19 \%$ & \multirow{2}{*}{ Softsign } \\
& Testing & $85,29 \%$ & \\
\hline \hline
\end{tabular}

Pengujian ketiga dilakukan dengan ekstraksi ciri menggunakan GLCM dan NGTDM. Dengan menggunakan fungsi aktivasi sigmoid biner, untuk data testing didapatkan jumlah citra retina yang diklasifikasikan ke tingkat keparahan yang tepat sebanyak 24 dari total 34 citra dan untuk data training didapatkan jumlah citra retina yang diklasifikasikan ke tingkat keparahan yang tepat sebanyak 81 dari total 105 citra.

Dengan menggunakan fungsi aktivasi sigmoid bipolar, untuk data testing didapatkan jumlah citra retina yang diklasifikasikan ke tingkat keparahan yang tepat sebanyak 27 dari total 34 citra dan data training didapatkan jumlah citra retina yang diklasifikasikan ke tingkat keparahan yang tepat sebanyak 96 dari total 105 citra. Sedangkan dengan menggunakan fungsi aktivasi softsign, untuk data testing didapatkan jumlah citra retina yang diklasifikasikan ke tingkat keparahan yang tepat sebanyak 26 dari total 34 citra dan untuk data training didapatkan jumlah citra retina yang diklasifikasikan ke tingkat keparahan yang tepat sebanyak 100 dari total 105 citra. Rincian hasil pengujian ini disajikan pada Tabel 5 dan hasil perhitungan akurasinya disajikan dalam Tabel 6.

Tabel 5.

Hasil pengujian dengan ekstraksi ciri GLCM dan NGTDM

\begin{tabular}{|c|c|c|c|c|c|}
\hline \multirow{2}{*}{$\begin{array}{c}\text { Fungsi } \\
\text { Aktivasi }\end{array}$} & \multirow[b]{2}{*}{$\begin{array}{l}\text { Hasil } \\
\text { Outpu } \\
t\end{array}$} & \multicolumn{2}{|c|}{ DataTesting } & \multicolumn{2}{|c|}{ Data Training } \\
\hline & & M & $\mathrm{S}$ & M & $\mathrm{S}$ \\
\hline Sigmoid & M & 7 & 0 & 22 & 1 \\
\hline Biner & S & 10 & 17 & 23 & 59 \\
\hline Sigmoid & M & 13 & 3 & 45 & 9 \\
\hline Bipolar & $S$ & 4 & 14 & 0 & 51 \\
\hline & M & 9 & 0 & 42 & 2 \\
\hline Softsign & $\mathrm{S}$ & 8 & 17 & 3 & 58 \\
\hline
\end{tabular}

Hasil perhitungan akurasi dengan ekstraksi ciri GLCM dan NGTDM

\begin{tabular}{cccc}
\hline \hline Fungsi & Data & Akurasi & Akurasi Total \\
Aktivasi & Training & $77,14 \%$ & $73,86 \%$ \\
Sigmoid & Testing & $70,59 \%$ & \\
Biner & Training & $91,43 \%$ & $85,42 \%$ \\
Sigmoid & Testing & $79,41 \%$ & \\
Bipolar & Training & $95,24 \%$ & $85,85 \%$ \\
& Testing & $76,47 \%$ & \\
Softsign & &
\end{tabular}

Dari hasil uji coba, hasil paling optimal didapat dengan menggunakan ekstraksi ciri dari GLCM dan fungsi aktivasi sigmoid bipolar. 


\section{Pembahasan Pengujian}

Hasil dari pengujian sistem menunjukkan akurasi terbesar didapat dari pengujian dengan ekstraksi ciri menggunakan GLCM dan fungsi aktivasi sigmoid bipolar yaitu sebesar $91,22 \%$. Penyebab utama rendahnya akurasi sistem klasifikasi tingkat keparahan NPDR berdasarkan hard exudate menggunakan Extreme Learning Machine adalah proses segmentasi yang tidak sempurna. Banyaknya wilayah nonexudate yang ikut tersegmentasi membuat kualitas informasi (ciri) pada proses ekstraksi ciri mengurangi tingkat akurasi sistem. Selain itu penentuan penggunaan fungsi aktivasi dan banyaknya node pada tiap layer pada model Extreme Learning Machine juga menentukan tingkat akurasi sistem.

\section{KESIMPULAN}

Berdasarkan uji coba pada bab sebelumnya, dapat diambil kesimpulan sebagai berikut:

1. Penelitian ini telah berhasil mengklasifikasikan tingkat keparahan NPDR berdasarkan hard exudate menggunakan Extreme Learning Machine dengan melakukan eliminasi optic disk dan segmentasi exudate terlebih dahulu. Karakterisktik citra exudate yang telah tersegmentasi diekstrak menggunakan GLCM dan digunakan sebagai masukan pada proses pelatihan dan pengenalan pada metode Extreme Learning Machine.

2. Sistem berhasil mencapai tingkat akurasi tertinggi menggunakan fungsi sigmoid bipolar pada model Extreme Learning Machine yaitu sebesar 91,22 \%. untuk ektraksi ciri menggunakan GLCM. Sedangkan untuk ektraksi ciri menggunakan NGTDM dan gabungan GLCM dan NGTDM didapatkan tingkat akurasi tertinggi sebesar $90,74 \%$ dan $85,85 \%$ dengan mengggunakan fungsi aktivasi softsign.

3. Keakuratan sistem dipengaruhi oleh banyaknya ciri statistik yang dihasilkan pada proses ekstraksi ciri. Segmentasi exudate juga berpengaruh pada keakuratan sistem. Banyaknya daerah non-exudate yang ikut tersegmentasi akan memberikan hasil klasifikasi yang kurang akurat.

\section{DAFTAR PUSTAKA}

[1] World Health Organization, "World Health Day 2016: Beat diabetes," 2016. [Online]. Available: http://www.who.int/campaigns/world-healthday/2016/en/.

[2] World Health Organization, "Global report on diabetes," 2016. [Online]. Available: http://www.who.int/diabetes/global-report/en/.

[3] D. C. S. Vandarkuzhali, T. Ravichandran, "ELM Based Detection of Abnormality in Retinal Image of Eye Due to Diabetic Retinopathy," $J$. Theor. an Appl. Inf. Technol., vol. 66, no. 2, pp. 423-428, 2005.

[4] H. Tjandrasa, R. E. Putra, A. Y. Wijaya, and I. Arieshanti, "Classification of Non-Proliferative Diabetic Retinopathy Based on Hard Exudate Usig Soft Margin SVM," in International Conference on Control System, Computing and Engineering, 2013, pp. 376-380.

[5] R. Gowthaman, "Automatic Identification and Classification of Microaneurysms for Detection of Diabetic Retinopathy," Int. J. Res. Eng. Technol., vol. 3, pp. 464-473, 2014.

[6] K. Haralick, R. M. Shanmugam and I. Dinstein, "Textural Feature for Image Classification," in IEEE Transactions on System, Man and Cybernetics, 1973, pp. 610-621.

[7] M. Amadasun and R. King, "Textural Features Corresponding to Textural Properties," in IEEE Transactions on System, Man and Cybernetics, 1989, pp. 1264-1274.

[8] G. B. Huang, Q. Y. Zhu, and C. K. Siew, "Extreme Learning Machine: A new Theory and Applications," Neurocomputing, vol. 70, pp. 489-501, 2006.

[9] MESSIDOR, "Methods for Evaluating Segmentation and Indexing techniques Dedicated to Retinal Ophthalmology," 2004. [Online]. Available: http://www.adcis.net/en/Download-ThirdParty/Messidor.html. 